\title{
IDENTIFIKASI KESULITAN BELAJAR READING COMPREHENSION DALAM UJIAN TOEFL PADA MAHASISWA DI LINGKUNGAN UNIVERSITAS MUHAMMADIYAH PALANGKARAYA
}

\author{
Oleh \\ A'am Rifaldi Khunaifi
}

\begin{abstract}
ASBTRAK
Pelitian ini bertujuan untuk mengetahui alasan atau faktor yang dominan mengapa Mahasiswa mengalami kesulitan dalam soal Reading Comprehension pada ujian TOEFL pada Mahasiswa di Lingkungan Universitas Muhammadiyah Palangkaraya.

Subjek penelitian ini adalah Mahasiswa semester tinggi di Universitas Muhammadiyah Palangkaraya yang berjumlah 20 orang. Jenis penelirian ini adalah Deskriptif Kualitatif. Teknik pengumpulan data yang digunakan yaitu wawancara, observasi dan dokumentasi.

Hasil penelitian ini menunjukkan bahwa : Mahasiswa semester tinggi UM Palangkaraya kurang dapat menjawab pertanyaan dengan benar dan dalam menjelaskan makna kata sukar dalam bacaan yang dimiliki Mahasiswa sangat rendah dan belum dapat dikuasai oleh Mahasiswa. Untuk mengatasi mengatasi kesulitan membaca pada mahasiswa semester tinggi adalah melakukan berbagai latihan dan penugasan.
\end{abstract}

\section{Kata kunci : Kesulitan belajar dan Reading Comprehension}

\section{PENDAHULUAN}

\section{A. Latar Belakang Masalah.}

Bahasa sangat berperan dalam kehidupan kita sehari-hari, karena bahasa merupakan cara untuk mengkomunikasikan ide-ide kita kepada orang lain. Dengan bahasa semua orang dapat mengekspresikan perasaan, keinginan, pendapat dan kebutuhan masing-masing individu. Tanpa berbahasa maka akan sulit bagi setiap orang untuk memahami maksud dari perkataan orang lain.

Belajar bahasa Inggris sangatlah komplek karena bahasa Inggris memiliki empat kemampuan dasar yaitu Listening (mendengar/menyimak), Speaking (berbicara), Reading (membaca) dan Writing (menulis). Serta memiliki tiga kemampuan tambahan yaitu Grammar (tatabahasa), Vocabulary (kosa kata) dan Pronunciation (pengucapan). Semua komponen itu sangat penting dan harus dipelajari jika ingin menguasai bahasa Inggris dengan baik.

Khususnya di Universitas Muhammadiyah Palangkaraya menganggap penting bahasa Inggris yang ditunjukkan melalui tes TOEFL dan memenuhi skor 475sebelum mereka Yudisium dan telah menyelesaikan sidang skripsi dalam satu semester. Tes TOEFL ini bertujuan agar setiap mahasiswanya dapat menjadi seorang sarjana yang berkualitas, yaitu mampu untuk mengungkapkan ide secara lisan maupun tulisan dalam bahasa Inggris. Dengan demikian mereka akan mudah mencari pekerjaan di tengah-tengah persaingan dalam bidang pekerjaan sekarang ini. Selain itu tes TOEFL ini juga dapat mempermudah mahasiswa yang ingin melanjutkan sekolah ke luar negeri. 
Tetapi pada kenyataannya, tidak sedikit mahasiswa yang masih belum dapat memahami makna bahkan tidak mengerti kata atau kalimat yang dibaca dalam bahasa Inggris. Ini artinya bahwa keterampilan pemahaman membaca (Reading Comprehension) dalam bahasa Inggris mereka masih kurang dan vocabulary yang mereka kuasai masih sangat terbatas.

Selain itu, mahasiswa juga merasa kesulitan untuk lulus tes TOEFL karena soal-soal yang diberikan sulit. Persoalan yang diberikan selalu berbeda setiap tes sehingga tidak memiliki bayangan terhadap soal-soal tes TOEFL tersebut. Pada bagian Reading Comprehension mereka merasa sulit karena pilihan jawaban yang diberikan hampir semuanya tepat sehingga mereka bingung untuk memilih jawaban yang tepat dan sesuai dengan bacaan yang diberikan. Selain itu, mereka pun lupa terhadap penggunaan tenses dan vocabularry dalam bahasa Inggris. Hal ini membuat mahasiswa harus mengikuti lebih dari tiga kali tes TOEFL untuk dapat lulus.

Menurut Budiyanto (Darmiyati Zuchdi, 2012: 17) yang mengatakan bahwa membaca dan menulis menrupakan instrumen utama dari tradisi keilmuan yang menjadi pemicu perubahan seuatu bangsa.

TOEFL adalah singkatan dari Test of English as Foreign Language atau Tes Bahasa Inggris sebagai bahasa asing, yangdiorganisir oleh sebuah lembaga di Amerika Serikat yang bernama ETS (Educational Testing Service). Pada awalnya, TOEFL diperlukan bagi para pelajar di negaranegara yang bahasa utamanya bukan bahasa Inggris, tetapi ingin melanjutkan studi ke negara-negara yang bahasa resminya adalah bahasa Inggris, seperti Amerika Serikat, Kanada, dan negaranegara Eropa Barat.Ini diperlukan untuk memastikan bahwa siswa-siswa dari negara berbahasa non-bahasa Inggristersebut dapat mengikuti perkuliahan di negara berbahasa Inggris dengan baik. Bahkan negara-negara yang bahasa ibunya bukan bahasa Inggris, seperti Jepang, Korea, India, Malaysia, Indonesia mensyaratkan TOEFL Score tertentu bagi calon mahasiswanya, baik yang datang dari dalam negeri, apalagi jika berasal dari luar negeri. Di Indonesia, TOEFL bahkan digunakan juga untuk persyaratan bagi penerimaan karyawan baru di instansi pemerintah, perusahaan pemerintah dan swasta, syarat penerimaan mahasiswa baru untuk jenjang S2 dan S3, syarat pengajuan beasiswa, baik dari pemerintah maupun swasta.

\section{B. PEMBAHASAN}

Pendapat Anderson (dalam Tarigan, 2015:21 ) bahasa adalah suatu sarana komunikasi. Pertama-tama bahasa itu tidak hanya dipahami atau dimengerti oleh pemakai, tetapi juga harus dipahami oleh orang lain. Kalau ucapan salah dimengerti, tidak dapat dipahami, atau bentuk-bentuk menyatakan suatu makna yang lain dari yang dimaksud oleh seseorang, gagallah bahasa mengkomunikasikan mereka, jelaslah terlihat bahwa pemakaian yang baku itusangat penting. Bahasa sebagai alat komunikasi yang mempunyai peranan penting dalam kehidupan individu maupun kelompok.

Anderson (dalam Tarigan, 2015: 19-22) mengatakan bahwa ada delapan prinsip dasar bahasa yang merupakan hakikat bahasa itu:

a. Bahasa adalah suatu system. Suatu system pola-pola yang kompleks dan suatu struktur dasar.

b. Bahasa adalah vocal. Hanya ujaran sajalah yang mengandung segala tanda utama suatu bahasa. Huruf- 
huruf merupakan sarana dan upaya untuk mewakili bunyi-bunyi suatu bahasa.

c. Bahasa tersusun dari lambinglambang arbitrer.

d. Setiap bahasa bersifat unik, mempunyai cirri khas.

e. Bahasa dibangun dari kebiasaankebiasaan.

f. Bahasa adalah sarana komunikasi

g. Bahasa berhubungan dengan budaya setempat.

h. Bahasa itu berubah dan dinamis

Dari beberapa pendapat para ahli di atas dapat disimpulkan bahwa bahasa adalah sebagai alat komunikasi antara anggota masyarakat berupa simbol bunyi yang dihasilkan oleh alat ucap manusia yang bersifat arbitrer dan konvensional, yang dipakai sebagai alat untuk berkomunikasi antar individu untuk melahirkan perasaan dan pikiran yang telah disepakati dalam suatu masyarakat. Bahasa merupakan suatu system yang tidak dapat berdiri sendiri.

\section{Keterampilan Bahasa.}

Keterampilan berbahasa dalam bahasa Inggris disebut language art andskills. Istilah art "seni", kita pergunakan untuk melukiskan sesuatu yang bersifat personal, kreatif, dan orisinal. Sebaliknya skill "keterampilan" dipakai untuk menyatakan sesuatu yang bersifat mekanis, eksak, dan impersonal. MenurutTarigan (2015:2) keterampilan berbahasa mempunyai empat komponen, yaitu keterampilan menyimak (listening skills), keterampilan berbicara (speaking skills), keterampilan membaca (reading skills) dan keterampilan menulis (writing skill). Setiap keterampilan itu erat sekali hubungannya dengan ketiga keterampilan lainnya dengan cara yang beraneka ragam. Dalam memperoleh keterampilan berbahasa, kita melalui hubungan yang teratur dan berkaitan antara satu keterampilan satu dengan yang lainnya. Menyimak dan berbicara kita pelajari sebelum masuk sekolah. Mula-mula pada masa kanak-kanak kita menyimak bahasa yang dipakai oleh orang di sekitar kita, kemudian dari kata-kata yang telah kita peroleh dari proses menyimak tadi kita belajar berbicara, baru setelah itu kita belajar membaca dan menulis. Keempat keterampilan tersebut pada dasarnya merupakan satu kesatuan yang disebut caturtunggal.

\section{ReadingComprehension}

Hal yang penting diperhatikan dalam kegiatan membaca ialah kemampuan seseorang untuk memahami makna bacaan secara menyuluruh, atau yang disebut dengan kemampuan pemahaman membaca. Menurut Rubin (Samsu Somadayo, 2011: 7) pemahaman membaca adalah proses intelektual yang kompleks yang mencakup dua kemampuan utama yaitu penguasaan makna kata dan kemampuan berpikir tentang konsep verbal.

\section{Pengertian Kesulitan Belajar.}

Martini Jamaris (2013: 3) menjelaskan bahwa kesulitan belajar ataulearning disabilities yang biasa juga disebut dengan istilah learning disorderatau learning dificulty adalah suatu kelainan yang membuat individubersangkutan sulit untuk melakukan kegiatan belajar secara efektif. Senadadengan pendapat di atas Mulyono Abdurrahman (2003: 6) menyatakanbahwa kesulitan belajar adalah suatu gangguan dalam satu atau lebih dariproses psikologis dasar yang mencakup pemahaman dan penggunaan Bahasa ajaran atau tulisan. 


\section{Kesulitan Belajar Membaca}

$\begin{array}{lrr}\text { Menurut Lerner } & \text { (Mulyono } \\ \text { Abdurrahman, } & \text { 2009: } & 200) \\ \text { kemampuanmembaca merupakan dasar } \\ \text { untuk menguasai bidang } & \text { studi. Jika } \\ \text { anak pada usia sekolah dasar tidak } & \text { dak } \\ \text { segera mempunyai kemampuan } & \text { kemalami } \\ \text { membaca makaia akan mengalami } & \text { mempelajari } \\ \text { banyak kesulitan dalam melas } \\ \text { bidang studi padakelas-kelas } \\ \text { berikutnya. Oleh karena itu anak harus } \\ \text { belajar membaca agaria dapat membaca } \\ \text { untuk belajar. } \\ \text { Farida Rahim dalam H Amalina }\end{array}$ (2012: 14) mengartikan membacamenjadi lebih detail dan spesifik, yaitu Kegiatan membaca meliputi tigaketerampilan dasar yaitu recording, decoding, dan meaning. Recordingmerujuk pada kata-kata dan kalimat, kemudian mengasosiasikannyadengan bunyibunyinya sesuai dengan sistem tulisan yang digunakan.Proses decoding merujuk pada proses penerjemahan rangkaian grafis kedalam kata-kata. Sedangkan meaning merupakan proses memahamimakna yang berlangsung dari tingkat pemahaman, pemahamaninterpretatif, kreatif, dan evaluatif. Proses recording dan decodingberlangsung pada siswa kelas awal, sedangkan meaning lebih ditekankanpada kelas tinggi. Dari pengertian beberapa tokok di atas penelitimenyimpulkan bahwa membaca merupakan proses mengenal danmengasosiasi huruf sehingga menjadi kata dan kalimat yang bermakna.

\section{Faktor Penyebab Kesulitan Belajar Membaca}

Menurut Martini Jamaris, (2013: 137-139) mengemukakan bahwa faktor penyebab kesulitan membaca disebabkan oleh beberapa hal antara lain yaitu a. Faktor fisik

Faktor fisik meliputi beberapa hal yaitu kesulitan visual atau penglihatan, kesulitan auditory persepsion atau ketajaman pendengaran, dan masalah neurologis.

b. Faktor Pisikologis

Faktor ini meliputi kesulitan dalam mengendalikan emosi, intelegensi atau IQ yang kurang dan konsep diri.

c. Sosio-Ekonomi

Kesulitan membaca yang disebabkan oleh faktor sosioekonomi meliputi faktor dari keadaan rumah yang kurang kondusif untuk belajar yang menyebabkan anak-anak yang berasal dari keluarga 15 kurang mampu mengalami hasil belajar di bawah potensi yang dimilikinya.

d. Faktor Penyelenggaraan Pendidikan Yang Kurang Tepat Faktor ini berkaitan dengan halhal sebagai berikut: (1) Harapan guru yang terlalu tinggi tidak sesuai dengan kemampuan anak, (2) Penggelolaan kelas yang kurang efektif, (3) Guru yang terlalu banyak mengeritik anak, (4) Kurikulum yang terlalu padat, sehingga hanya dapat dicapai oleh anak yang berkemampuan tinggi.

\section{METODE PENELITIAN}

Beni Ahmad Saebani (2009:41) mengatakan bahwa penelitian adalah merupakan suatu kegiatan yang ditujukan untuk mengetahui seluk beluk sesuatu. Kegiatan ini biasanya muncul dan dilakukan karena ada suatu masalah yang memerlukan jawaban atau ingin membuktikan sesuatu yang telah di alami selama hidup atau mengatahui berbagai latar belakang terjadinya sesuatu. Sedangkan menurut Sigit Santoso (2011:25) Metodologi 
penelitian adalah strategi umum yang diikuti dalam pengumpulan dan analisis data dalam upaya menjawab suatu pertanyaan.

\section{Diskriptif Kualitatifmerupakan penelitian yang bertujuan untuk mendapatkan informasi mengenai fenomena-fenomena atau situasi yang aktual atau yang ada pada saat penelitian berlangsung (Sigit Santoso 2011:25)}

Desain Teknik Samplingdalam penelitian kualitatif adalah untuk menjaring atau mencari informasi dari berbagai sumber dan bertujuan untuk merinci kekhususan dari berbagai sumber data serta untuk menggali informasi yang akan menjadi dasar dari rancangan dan teori yang muncul. Sampel dapat diambil dengan menggunakan Teknik sampel bertujuan (Purposive Sampling).

Menurut Sugiyono (2016:85) bahwa: "purposive sampling adalah teknik pengambilan sampel sumber data dengan pertimbangan tertentu." Alasan menggunakan teknik Purposive Sampling adalah karena tidak semua sampel memiliki kriteria yang sesuai dengan fenomena yang diteliti. Oleh karena itu, penulis memilih teknik Purposive Sampling yang menetapkan pertimbangan-pertimbangan atau kriteria-kriteria tertentu yang harus dipenuhi oleh sampel-sampel yang digunakan dalam penelitian ini.

Menurut Notoatmodjo (2010) pengertian Purposive Sampling adalah: pengambilan sampel yang berdasarkan atas suatu pertimbangan tertentu seperti sifat-sifat populasi ataupun ciri-ciri yang sudah diketahui sebelumnya.

\section{Subyek Penelitian.}

Penelitian ini dilakukan pada 20 orang subyek dari berbagai prodi yang ada dilingkungan Universitas
Muhammadiyah Palangkaraya. Teknik penentuan subyek

\section{HASIL}

Penelitian pertama mahasiswa diberikan pertanyaan oleh instruktur mengenai unsur intrinsik yang ada pada bacaan cerita pendek yang berjudul "The Goose with the Golden Eggs". Ketika instruktur memberikan pertanyaan kepada mahasiswa, respon yang diberikan adalah diam. Kemudian instruktur mengulang kembali pertanyaan kepada mahasiswa dengan bahasa yang sederhana dan mudah dimengerti.

Pada penelitian kedua mahasiswa UM Palangkaraya kembali diberikan pertanyaan mengenai bacaan yang telah dibacanya yaitu dengan judul "The Ant and The Dove". Peneliti menanyakan kembali unsur intrinsik yang ada dalam cerita tersebut. Mahasiswa kembali ditanya namun hal yang sama seperti pada penelitian hari pertama ia mengalami kesulitan untuk dapat menjawab pertanyaan dari instruktur.

Hasil penelitian hari ke tiga yaitu mahasiswa diberikan pertanyaan mengenai isi bacaan yang ada pada teks. Mahasiswa kurang mampu menjawab pertanyaan sesuai dengan isi bacaan. Mahasiswa terlihat kebingungan dan hanya melihat jawaban dari teman lainnya dan kemudian menuliskan jawabannya di buku tulisnya. Pada saat diberikan pertanyaan lisan mahasiswa hanya terdiam dan justru hanya tersenyum ketika instruktur menanyakan soal bacaan yang telah dibacanya. Instruktur memberikan pertanyaan sesuai dengan isi bacaan, yaitu menanyakan sesuai dengan teks yang diberikan kepada mahasiswa.

Pada penelitian ke empat pembelajaran praktek yang dilaksanakan adalah menjawab 
pertanyaan di latihan soal. Setiap soal terdapat bacaan dimana mahasiswa mampu menjawab pertanyaan namun ada beberapa pertanyaan yang tidak dijawab dengan tepat.

Hasil penelitian ke limamahasiswa UM Palangkaraya mampu menjawab pertanyaan yang diberikan oleh instruktur, meskipun instruktur harus mengulang pertanyaan dan membuat pertanyaan menjadi sederhana.

\section{SIMPULAN}

Berdasarkan hasil penelitian dan pembahasan yang telah dilakukan dapat diketahui bahwa kesulitan belajar Reading Comprehension pada mahasiswa semester tinggi UM Palangkaraya maka dapat disimpulkan bahwa :

Mahasiswa semester tinggi UM Palangkaraya kurang dapat menjawab pertanyaan dengan benar namun ketika instruktur mengulang pertanyaan atau menyederhanakn sebuah kalimat pertanyaan yang diberikan dan mahasiswa mengulang kembali bacaan maka mahasiswa akan dapat menjawab pertanyaan dari instruktur meskipun jawaban yang diberikannya tidak maksimal.

Kemampuan menjelaskan makna kata sukar dalam bacaan yang dimiliki mahasiswa sangat rendah dan belum dapat dikuasai mahasiswa. Mahasiswa harus diberikan pertanyaan dan kalimat yang sederhana agar dapat dimengerti oleh mereka. Kemampuan menceritakan kembali isi bacaan pada mahasiswa semsester tinggi UM Palangkaraya tergolong dalam kategori cukup, dikarenakan hanya sebagian isi bacaan yang dapat diceritakan mahasiswa.

\section{DAFTAR PUSTAKA}

Darmiyati Zuchdi. 2012. Terampil Membaca dan Berkarakter Mulia. Yogyakarta: Multi Presindo.

Deded Koswara. (2013). Pendidikan Anak Berkebutuhan Khusus Berkesulitan Belajar Spesifik. Bandung: Luxima metro media.

Martini Jamaris. (2013). Kesulitan Belajar Perspektif, Asesmen, Dan Penanggulangannya. Jakarta: Ghalia Indonesia.

Mulyono Abdurrahman. (2009).Pendidikan bagi anak berkesulitan belajar.Jakarta: Rineka Cipta.

Notoatmodjo, S. 2010. Metodologi Penelitian Kesehatan. Jakarta : Rineka Cipta

James, McLeskey., Michael S. Rosenberg., \& David L. Westling. 2013. Inclusion Effective Practices for All Students. Pearson: United State America.

Pollard, Lucy. (2008). Teaching English. UK: Longman.

Samsu Somadayo. 2011. Strategi dan Teknik Pembelajaran Membaca. Yogyakarta: Graha Ilmu.

Sugiyono.2010. Metode Penelitian Kuantitatif Kualitatif. Bandung: CV Alfa Beta

Sugiyono. (2016). Metodologi Penelitian Kuantitatif, Kualitatif, dan R\&D. Bandung: CV Alfabeta

Tarigan, Henry Guntur. (2015). Menyimak Sebagai Suatu Keterampilan Berbahasa. Bandung : Angkasa.

A'am Rifaldi Khunaifi 